Cahiers $d u$ MONDE RUSSE

\section{Cahiers du monde russe}

Russie - Empire russe - Union soviétique et États indépendants

\section{$57 / 1 \mid 2016$}

Terres, sols et peuples : expertise agricole et pouvoir (xixe - xxe siècles)

\title{
Sweet Development
}

The sugar beet industry, agricultural societies and agrarian transformations in the Russian empire 1818-1913

Un développement doux : l'industrie de la betterave sucrière, les sociétés agricoles et les transformations agraires dans l'Empire russe, 1818-1913

\section{Susan Smith-Peter}

\section{OpenEdition}

\section{Journals}

Electronic version

URL: http://journals.openedition.org/monderusse/8334

DOI: 10.4000/monderusse.8334

ISSN: $1777-5388$

\section{Publisher}

Éditions de l'EHESS

\section{Printed version}

Date of publication: 1 January 2016

Number of pages: 101-124

ISBN: 978-2-7132-2540-6

ISSN: $1252-6576$

\section{Electronic reference}

Susan Smith-Peter, «Sweet Development », Cahiers du monde russe [Online], 57/1 | 2016, Online since 01 January 2019, Connection on 20 April 2019. URL : http://journals.openedition.org/ monderusse/8334 ; DOI : 10.4000/monderusse.8334

This text was automatically generated on 20 April 2019.

(c) École des hautes études en sciences sociales 


\section{Sweet Development}

The sugar beet industry, agricultural societies and agrarian

transformations in the Russian empire 1818-1913

Un développement doux : l'industrie de la betterave sucrière, les sociétés

agricoles et les transformations agraires dans l'Empire russe, 1818-1913

\section{Susan Smith-Peter}

1 Russian agricultural societies were voluntary associations that linked governmental and private actors with the hopes of transforming Russia's environment and economy. This article explores how one agricultural society-the Moscow Agricultural Society, established in 1818-encouraged the cultivation of sugar beet in European Russia as a substitute for cane sugar. While the government was not sympathetic, it indirectly assisted the sugar beet industry through its policies on taxes and tariffs. Even before the abolition of serfdom in 1861, the society had successes in spreading the cultivation of sugar beets and encouraging the production of beet sugar, which required complex machinery. Entrepreneurial nobles were able to change their agricultural practices without state assistance, relying mainly on free labor and on motivating serfs to plant sugar beets by paying money. Such nobles were scattered throughout the Russian Empire, and the Moscow Society played a key role in assisting them with seeds and improved technology.

2 At the same time, the Moscow Society was not able to transform the environment in the way they had originally hoped, which was to change European Russia by encouraging small noble producers to shift to growing sugar beet, which would then be processed in the factories of wealthy nobles. Instead, what began to emerge even before 1861 was the rise of extremely large vertically integrated producers in central and southern Ukraine, which is particularly rich in the soil best suited for growing sugar beets. While the patchwork of small and large producers in European Russia needed the tutelage of the Moscow Society to establish the industry, the massive Ukrainian producers required neither packets of seeds nor training for their stewards in the basics of beet sugar production. This article argues that although the work of the Moscow Society was important for introducing the cultivation of sugar beet, ultimately the superior soil found 
in the central and southern Ukrainian provinces, along with the spread of free labor and advanced technology there, allowed for the emergence of a highly successful beet sugar industry that was different from what the Moscow Society had originally envisioned.

This article contributes to three major areas of study: Ukrainian and Russian economic history, and the activities of voluntary associations. Ukrainian economic history has attracted scholars for many years, and classic works imply that Ukraine's economic growth gave it a possible basis for autonomy. ${ }^{1}$ However, the main focus of Ukrainian history traditionally was to trace the growth of the Ukrainian idea via its ideological bearers and the conflicts they encountered with the Imperial Russian state. The populist thrust of classic historical narratives made it difficult to integrate the growth of factories, which Populists saw as exploitative, into a narrative of an emerging nation. ${ }^{2}$ Newer work deals with the interaction of various ethnic groups in regions of Russia. ${ }^{3}$ Comparing Ukrainian and Russian economic development before 1861 helps to explain one aspect of Ukraine's divergence from Russia.

The history of the rise of market agriculture in Russia has long occupied historians, as it is one part of the long-running debate about capitalism in pre-revolutionary Russia. ${ }^{4}$ In the 1960s, economic historians focused on the role of the state in accelerating a shift from subsistence to market agriculture; in particular, Alexander Gerschenkron argued that Russian agriculture contributed to Russian backwardness due to low yields resulting from serfdom and the peasant commune and that the state had to drive industrialization forward as a result. ${ }^{5}$ More recently, Carol S. Leonard has argued that the state failed to implement agrarian reform due to the lack of instruments at its disposal, particularly at the local level. ${ }^{6}$ In the 1970s and 1980s, historians brought the Gershenkron model into question by arguing that development happened even under serfdom and that the state was not the only source of economic development; they also noted the importance of foreign investment in the late Imperial period and the influence of enterprising nobles before $1861 .{ }^{7}$ Newer works also critique the state-led argument, and take part in an intellectual turn in Russian economic history, shifting from a heavily quantitative discipline to one interested in changing ideas about the economy, generally focusing on the most important figures in this process. ${ }^{8}$ This article focuses on both broader social groups and on individuals to introduce a new collective actor in the economic and intellectual history of Russia: the agricultural societies.

5 Scholars working on agricultural societies have given widely varying evaluations of how much impact they had on agricultural practice. The first works were the jubilee histories written by leaders of societies themselves; not surprisingly, they emphasized their important achievements. ${ }^{9}$ In his classic works, Michael Confino noted that agricultural societies worked with the state to attempt to change agricultural practice, but he questioned whether they had any real impact. ${ }^{10}$ However, because Confino focused on changes to the three-field system in central Russia, developments in Ukraine and in beet sugar production were outside the scope of his work. Sugar beets could be grown in peasant vegetable plots without changing the three-field system, but nevertheless were part of improved agriculture. David Moon has noted that agricultural improvements were most common in southern Russia and Ukraine. ${ }^{11}$ Tracy Dennison argues that we know little of pre-1861 agricultural practice and that attention to the local and regional is needed in order to build our knowledge. ${ }^{12}$ Newer works on agricultural societies argue that they did influence agricultural science and practice, both before and after $1861 .^{13}$ After 1861, there was a shift from a limited number of noble-dominated voluntary 
associations to a more broad based series of societies and cooperatives. ${ }^{14}$ By taking sugar beet production as a case study, this article helps to give a more nuanced understanding of how even when some societies were initially successful at spreading new crops and technologies, the small-scale agrarian industrialization they hoped for in central Russia was supplanted by massive factories in Ukraine.

Even smaller scale producers had to deal with a process that required some knowledge and complex machinery, as first the beets would be grated and boiled, and the juice pressed from them. This juice would then be purified by saltpeter or other chemical means and then evaporated. The resulting syrup would be boiled until it crystalized, a process that required a refinery, meaning that smaller producers often had to sell syrup rather than crystalized sugar if there was no refinery nearby. When the first large refinery appeared in Kiev in 1843, rather than in Moscow, it was an early sign of the shift in the center of the industry. ${ }^{15}$

\section{The State and the Russian sugar beet industry : the politics of taxes and tariffs}

7 Sugar was not only a consumer good but also a matter of state. In Russia, levies of various sorts on sugar were a major source of the state's income, and there were debates about which levies on which type of sugar would bring in the optimum income for the state. Sugar is produced both from sugar beets and from cane. Due to the influence of the refiners of raw sugar in St. Petersburg, for much of the nineteenth century, refined cane sugar could not legally be imported into Russia, aside from Odessa and a few other Black Sea ports. Raw cane sugar was imported to St. Petersburg, where sugar refineries produced the finished product. Sugar beets could be grown over a large swathe of the central and southern parts of the Russian Empire, although they also required a refinery to produce refined sugar.

8 The state had to raise money through tariffs and taxes without driving sugar prices so high that smuggling or reduced consumption would decrease the government's income from such levies. It also had to navigate between the pressures applied by the St. Petersburg cane refiners and the emerging sugar beet industry. This section seeks to tease out the main turning points and influences in the development of the sugar beet industry in the first half of the nineteenth century. Between 1800, when the sugar beet industry was in its infancy, and 1848, when the first excise was placed on beet sugar, the state was most interested in raising money through levies on cane sugar while placating the St. Petersburg refiners, but they also inadvertently stimulated the growth of the sugar beet industry.

9 Sugar cane produces a large amount of sugar from each plant, and during the colonization of the New World, European countries introduced a colonial system in which imported African slaves worked on sugar cane plantations, in the harshest of conditions, and the sugar was often sold exclusively to the colonizing country or to other countries without tropical colonies at high prices. ${ }^{16}$ Although experiments with extracting sugar from beets had begun as early as the seventeenth century, it was Franz Carl Achard who, in 1799 in Austria, perfected the process, winning praise from Napoleon, who predicted Britain would have to throw its sugar into the Thames, as the Continent's sugar would now come from beets. ${ }^{17}$ 
sugar. Napoleon put the resources of the state behind the promotion of beet sugar, creating six experimental sugar beet stations and assigning one hundred students to them. He spent lavishly on supporting the cultivation of sugar beet and by 1812-1813, 309 of the 334 sugar factories in Continental Europe were in France. ${ }^{18}$ During the Napoleonic Wars, prices for cane sugar in Russia and elsewhere reached unprecedented heights due to the Continental System, which Napoleon instituted between 1806 and 1814 in order to prevent much of continental Europe from trading with the United Kingdom, a major supplier of cane sugar. In 1800, Emperor Alexander I approved measures to give free land to those who would grow sugar beets, to reward those who established beet sugar factories and successfully grew sugar beets. ${ }^{19}$ Sometime between 1800 and 1802, a sugar factory was established on an estate in Tula became the first widely known sugar factory and spurred nobles in central Russia to imitations. ${ }^{20}$ By 1810, there were four such factories in Russia, and by 1812 there were $10 .{ }^{21}$

11 Napoleon's invasion of Russia, which began on June 24, 1812, increased sugar prices to new highs and spurred interest in producing beet sugar. Not surprisingly, there was interest in how to make beet sugar during this period; in 1812, a newspaper in Kazan provided information on how to make beet sugar crystallize faster. ${ }^{22}$ With the resumption of French trade with Britain in 1814 came the collapse of the sugar beet industry in France, which did not recover until the 1840 s. ${ }^{23}$ However, in Russia, sugar beets continued to be widely grown, to the point that the St. Petersburg refiners began to criticize the new industry. ${ }^{24}$

In 1822, the government levied a high tariff on raw cane sugar that amounted to 15 percent of its value, and forbade refined cane sugar to be imported into Russia. ${ }^{25}$ The effect was protectionist for beet sugar, even if the intent of the government was to raise money. At the same time, prices for grain in domestic and European markets were so low that growers were not able to cover their costs. ${ }^{26}$ In 1822, a protectionist tariff on grain expired, driving its price still lower. ${ }^{27}$ There was a harvest failure in 1822 that was due to a changing climate. ${ }^{28} \mathrm{As}$ a result, Russian landowners engaged in the market were looking for a crop that could offset the losses they were incurring.

The new tariff proved to be a turning point. In 1822, there were only two sugar beet factories that made up to 1500 poods of granulated sugar. ${ }^{29}$ One of them was the factory of I.A. Mal'tsov, who was the key figure in the spread of the beet sugar industry in this era. Working with the Moscow Agricultural Society, Mal'tsov indefatigably spread information about the technical and agricultural aspects of beet sugar production, as will be discussed below. In 1825, there were eight beet sugar factories; by 1832, twenty had appeared..$^{30}$

14 In 1832, despite complaints of the St. Petersburg refiners that domestic beet sugar was competing with cane, Minister of Finances Egor Frantsevich Kankrin raised the tariff on cane sugar from 2 rubles 50 kopecks a pood to 3 rubles 15 kopecks, which was 34 percent of its value. ${ }^{31}$ This very high tariff further stimulated the beet sugar industry by inflating the price of sugar. More nobles became interested in growing sugar beets, and in 1834, a group of beet sugar producers founded the Committee of Sugar Beet Manufacturers within the Moscow Agricultural Society. ${ }^{32}$ By the late 1830s, sugar beet production had begun to spread to left bank Ukraine. ${ }^{33}$ By 1840 , the number of beet sugar factories in the Russian Empire had jumped to $140 .{ }^{34}$ 

famine of 1833, the government focused on the need for subsistence items, and sugar was not needed for survival. ${ }^{35}$ Minister of Finances Kankrin was suspicious of the growth of the sugar beet industry and noted in 1833: "The beet-sugar industry is one of the most illfounded projects of the Russian gentryman." ${ }^{36}$ Nicholas I was also personally hostile to the cultivation of the sugar beet, believing it would damage the soil. ${ }^{37}$ The government did not prevent landlords from engaging in the sugar beet business, but they refused to make loans to nobles on sugar, even though they did so on nearly all other agricultural products..$^{38}$ However, it is possible that Kankrin's comment, which came a year after he levied such a high tariff on cane sugar, was a sort of demonstrative grumbling to placate the refiners. ${ }^{39}$ extremely high levy started to impact the amount of revenue collected as people limited their consumption. Customs revenues from sugar were 3.7 million rubles in 1831, and rose to 8 million in 1844 due to the high tariff, but fell to less than 5.5 million rubles in 1847 due to people reducing their consumption of sugar. ${ }^{41}$ The refiners were in a position to complain more effectively as the state felt the impact in its pocket. In 1847, the secretary of the Moscow Agricultural Society, Stepan Alekseevich Maslov heatedly denied that the 1841 tariff had stimulated the development of the industry, saying that the extremely low prices for grain were the real force behind the industry's spread. ${ }^{42}$ However, the intensity of the denial could not hide the connection between the tariff and the growth of the industry. ${ }^{43}$ The number of sugar factories jumped from 140 in 1840 to 350 in 1848, the largest increase of any eight-year period between 1810 and 1914. ${ }^{44}$

With the arrival of a new Minister of Finances, Fedor Pavlovich Vronchenko, the refiners found a more sympathetic ear. They complained that hurricanes in Cuba had hurt the crop there and that they needed the state to allow them to import raw and half-refined sugar from England, a concession that cost the state 579,000 silver rubles in 1845. The same "hurricane" took place in 1846 and 1847. The refiners also demanded that the government levy an excise on beet sugar. ${ }^{45}$

During this time, there were rumors of such an excise, and the Moscow Agricultural Society mobilized opinion against it publicly and privately. It is particularly interesting to analyze a letter, dated January 31,1845 , from Maslov to Petr Ivanovich Keppen, who was named head of the third division of the Ministry of State Domains in 1838 and was a member of the Scholarly Committee of that ministry in $1841 . .^{46}$ The two had been in correspondence since at least 1839 , and this is reflected in the informal nature of Maslov's style, which includes a frank discussion of the possibility of an excise on sugar beet:

To hit factory owners with a tax now would be simply stupid and harmful; give the industry some time to take root and only then go ahead and place a high levy on lump sugar, like tobacco and cigars; an excise will allow consumers to buy sugar 49 $1 / 4$ percent cheaper and the flow of producers out of the industry would kill it. ${ }^{47}$ Maslov then ended by saying that his speech on the progress of the sugar beet industry recently appeared in Moskovskie Vedomosti and asked if Keppen would be interested in "helping with publicity" by coauthoring articles with Maslov.

In his articles for the Moskovskie gorodskie listki in 1847, Maslov continued his propaganda campaign on behalf of the Committee of Sugar Beet Manufacturers, appealing to nationalism by saying that beet sugar could replace foreign cane sugar, to 
fears of change by saying it kept peasants in the villages and avoided creating proletarians, who had made life so difficult for English, French and German ministers, and to humanitarian feelings by saying that cane sugar was stained with the blood of slaves in Cuba and elsewhere..$^{48}$ Interestingly, in a series of articles critiquing Maslov's work, several authors argued that bringing down the price of sugar was more important than protecting the infant beet sugar industry, suggesting that Maslov's fear of lower prices, expressed only in private to Keppen, could be detected by his critics. ${ }^{49}$

In the end, the excise on beet sugar was approved on February $25,1848 .{ }^{50}$ However, Minister of State Domains Pavel Dmitrievich Kiselev interceded on behalf of the Moscow Agricultural Society to ensure that the norms set for the extraction of sugar from the beets were low. This meant that factories had a strong motivation to increase the amount of sugar they extracted from the beets, as the more they could exact, the less excise they paid in real terms. ${ }^{51}$ In practice, the excise hastened the shift from smaller, less efficient factories to large, advanced ones, particularly in Ukraine.

The shift of the center of the beet sugar industry to Ukraine meant the rise of large factories using advanced equipment and free labor. This laid the foundation for a competitive beet sugar industry in the Russian Empire. By the second half of the nineteenth century, sugar beets were widely grown in Europe and government policies, such as bounties that encouraged the import of sugar abroad, had led to an overproduction of sugar and a corresponding slump in prices on the world market, which fell by nearly half between 1856 and $1912 .{ }^{52}$ Even so, the Russian Empire continued to be a major producer of beet sugar, becoming the fourth-largest producer in Europe, after Germany, Austria-Hungary and France in 1890 and the second largest, after Germany, in $1917 .^{53}$

\section{The Moscow Agricultural Society and the origins of market agriculture in Russia}

The Moscow Agricultural Society (MAS) played a key role in introducing market agriculture into the Russian Empire. Through their publications, they spread knowledge about cash crops to landowners both large and small. They served as nurse to infant industries like sugar beets. The MAS was part of a European-wide social network of scholars, landlords, and government officials interested in encouraging agricultural production. During the eighteenth century, much of Europe experienced rising prices along with rising population and urbanization. At the same time, the Enlightenment provided new scientific studies of agriculture that promised an increase in production sufficient to feed the cities. Governments in central and Eastern Europe, including those in the German lands, the Hapsburg Empire and the Russian Empire encouraged the application of these new methods. ${ }^{54}$ In particular, market agriculture increased productivity by introducing fodder crops such as clover and new root vegetables such as the turnip and the rutabaga, which were capable of feeding more livestock and more people. The fallow land was planted with fodder crops for livestock, which in turn provided a greater amount of fertilizer so that the land could be used more intensively. ${ }^{55}$

Russian agricultural societies were established at around the same time as those in Europe and America. The first agricultural society in the world was the Society of Improvers in the Knowledge of Agriculture, founded in Scotland in 1723, but inactive 
after 1741. Established in 1731, the Dublin Society is the oldest such society that survives today, while the Royal Agricultural Society of England was established in 1838. In 1761, France established a royal society of agriculture. ${ }^{56}$ Just four years later, Catherine the Great established the Free Economic Society to improve Russian agriculture and industry by spreading new ideas and techniques; it drew upon the example of recently founded European voluntary societies to do so. The first American agricultural society was the Society for Promoting Agriculture, established in 1785. The 1850s and 1860s was a boom time in the creation of such societies in the West; at just that time they were most active in Russia as well. In the United States, there were nearly 2000 agricultural societies with roughly 400,000 members, or one in ten farmers. ${ }^{57}$ During the mid-nineteenth century, science had become more useful for farmers and was not yet the province of universities and governmental bodies. ${ }^{58}$ While agricultural societies in the pre-reform era were mainly the province of nobles and focused on education, by the late nineteenth century, many were credit associations that lent to peasants and other agriculturalists. ${ }^{59}$

The members of the MAS tended to be large landowners. One count of the 770 members that joined between 1818 and 1860 found that 621 of them, or 81 percent, had more than 100 male serfs, which was considered the minimum needed to allow a fully Westernized existence, while 211 , or 27 percent, owned more than 500, putting them among the wealthiest nobles. ${ }^{60}$ During its first few decades, its members believed technology could fix the problems of serf agriculture; when this hope was dashed by the 1840s, many became abolitionists. During the 1840 s, nobles were also influenced by a Romantic reevaluation of the peasantry as the bearer of Russian nationality rather than the Enlightenment image of them as obstacles to scientific agriculture. ${ }^{61}$ Before 1861, the MAS focused on nobles; afterwards, it spread agricultural information among the peasants. One of its successful programs in reaching the peasants was assisting with the creation of rural credit cooperatives; between 1865 and 1899, 568 cooperatives were established and by 1916 there were more than $5000 .^{62}$ The famed agrarian economist Alexander Chayanov came out of the MAS tradition, as he noted himself. ${ }^{63}$

The MAS worked closely with the government, but was still driven by its own interests. In 1836, many MAS administrators became government employees in that the government paid their salaries. ${ }^{64}$ This was in response to MAS vice-president Sergei Ivanovich Gagarin's request that the society's secretary, the director of the Society for Sheep Breeding, their assistants, and the senior and junior clerks become civil servants. ${ }^{65}$ These positions were administrative, not executive. The president, vice-president and council seats all remained independent of the government. Wealthy nobles filled these more powerful positions and did not require government compensation. The government created almost a shadow ministry in the MAS to deal with landlord serfs at the same time a new ministry was created to deal with state peasants; in 1837, Nicholas I approved the creation of the Ministry of State Domains (MGI), headed by Count Pavel Dmitrievich Kiselev, who conducted a major administrative reform of state peasants. ${ }^{66}$

However, this did not mean that the society lost all initiative. The government collected information from the society but did not give it orders. As MAS Secretary Stepan Alekseevich Maslov wrote, "the government stated its willingness to protect the Agricultural Societies, as the closest intermediaries between the landlords and the agriculturalists entrusted to their guardianship." ${ }^{67}$ In 1838 , Kiselev wrote to Golitsyn to inform him of the new order, noting that the establishment of the ministry included the right "to direct societies, serving for the dissemination of agricultural information." 68 
Kiselev asked only for annual published reports from the MAS, information on successful agricultural experiments, and "proposals the Society has for the future dissemination of useful innovations." ${ }^{\prime 69}$

The result was more a coordination of work than a control of it. In an 1858 letter to enlightened bureaucrat Andrei Parfent'evich Zablotskii-Desiatovskii, Maslov recalled a conversation he had had with Kiselev on the relationship of the ministry with the society. Maslov wrote that he had told Kiselev,

Preserve the society; in Russia it is easier to establish two ministries than one society. Why is this? Because in a ministry for each vacancy you will find up to two candidates searching for a job, but the society consists of free people, not bound by anything. Here moral strength is necessary so that the society can hold on and be active, especially among ourselves, who have not grown to fit the demands of societies. The count agreed. ${ }^{70}$

Despite the generally cordial relations between the government and the MAS, the society continued to promote sugar beet production in the face of government disinterest and hostility. The MAS was more than just a handmaiden of the state.

In 1822, at the moment when grain had hardly any value and enterprising landlords were seeking a cash crop, the Moscow Agricultural Society played a key role in convincing many that sugar beets were what they were looking for. In particular, Malt'sov, one of the pioneers of the industry, published an article stating that sugar beets were highly profitable. ${ }^{71}$ In fact, the budget published in the 1822 article showed that, after expenses, Malt'sov had made 9670 rubles in pure profit. ${ }^{72}$ According to Mal'tsov, beets took only a day to plant and required little extra care. Peasant women could grow them in their vegetable plots. In addition, they were harvested after the main harvest, which was a relatively slack time. The byproducts of sugar beet refining could be used to feed livestock and would increase milk production, the article stated. ${ }^{73}$ In other words, it was possible to start sugar beet production without serious reorganization of peasant agricultural practice-a major advantage for landlords both small and large.

The Moscow Agricultural Society encouraged nobles with fewer than 100 serfs, who made up the majority of the noble estate but who sometimes lived in a modest way not unlike their own serfs, to grow sugar beets and process them in small factories in order to expand the base of raw materials and encourage the consumption of sugar. ${ }^{74}$ Malt'sov's article did reach such small-scale but enterprising nobles, as we see in a detailed account from one Baron Kots, who had a small estate with only 84 peasants. In a letter to the Moscow Agricultural Society in 1833, he described how, after he retired from the military, he sought some cash crop that would make a profit on his small estate, as grain alone had little value and could be grown in quantities that just barely kept himself and his serfs from starvation. In reading the Society's journal, he came across Mal'tsov's article and decided to try his hands at growing sugar beets. The Society provided him with crucial technical help, as he did not have enough serfs to qualify for state loans, which were not given for sugar beet in any case. Kots took time to prepare for the beet sugar factory, sending one of his serfs as an apprentice to Malt'sov's factory in 1825, from whence he returned in 1827 with a certificate. In 1828, Kots was then able to build a successful factory and to encourage his serfs to grow sugar beets in their vegetable plots by giving a very high cash advance to one peasant, who spread the word all around the village. Once many peasants and some nobles began to provide him with beets, Kots then decreased the price he paid for beets. ${ }^{75}$ Kots is an excellent example of the small landlord who would not 
have been able to establish a sugar mill without the assistance of the Moscow Society's publications and members.

Owners of larger sugar mills also were influenced by Malt'sov to establish their own factories. This included Aleksei Nikolaevich Bakhmetev, who was the owner of a large, technically advanced factory in Penza province, located in southern Russia, just over 300 miles to the southeast of Tula, the original heartland of sugar beet production. ${ }^{76}$ Bakhmetev was an general from the infantry, a participant in the battle of Borodino, and served as the Governor-General of Nizhnii Novgorod, Kazan, Simbirsk and Penza provinces, as well as in the State Council. ${ }^{77}$ Penza province was in a favorable location for trade at the border of the steppe and forest zones, and had a tradition of market agriculture. ${ }^{78}$ This sugar beet factory was part of Bakhmetev's estate in Petrovka village, which also had a weaving factory, a hospital and school, along with crystal and glass factories nearby ${ }^{79}$ Bakhmetev was an enterprising landlord with enough capital to undertake major improvements and to produce for the market. In this, he was a model member of the MAS, which he joined in $1836 .{ }^{80} \mathrm{He}$ was among the middling and larger landlords who dominated the Committee of Sugar Beet Manufacturers. ${ }^{81}$

The Moscow Society held up Bakhmetev's factory as a model. At a May 19, 1832 meeting of the Moscow Society, the problems of the industry were discussed, including a lack of capital to buy steam-driven equipment and a difficulty in producing white granules, which were a medium-stage product. Only Bakhmetev had been able to produce white granules, the Society noted ${ }^{82}$ In 1835 , Bakhmetev's factory was one of only two sugar mills in the empire that used steam-driven machines. ${ }^{83}$

Letters from Bakhmetev's factory manager, Porfirii Riabinin, to Bakhmetev have survived, providing us with a rich source on the day-to-day workings of a beet sugar factory and the difficulties in establishing consistent quality control. However, despite these problems, the level of control over the product was enough that sale of the product did not suffer. Between 1837 and 1844, Riabinin wrote several times to report on progress or lack thereof. These letters suggest that only landlords with a high capitalization could afford to spend the money necessary to outfit the factories and cover the inevitable lulls in production. In addition, they show that processing sugar beet would be much easier in warmer regions. On August 23, 1838, Riabinin wrote that the factory was almost ready, with 23 workers already there and 58 more to come. ${ }^{84}$ Unfortunately, he did not mention if they were hired or serf labor. However, at least some of the more skilled overseer positions would have been hired, even if the rest were serfs. The condition of the workers at times concerned Riabinin. He wrote on December 6, 1839 that the boys in the factory "are not now zealous [because they have] no shirts and high boots. Would it not be possible to order that these be sent to the factory office?" ${ }^{85}$ The boys were not the only ones to suffer the cold. Some of the beets froze, which meant that it was difficult to produce the right sort of syrup. Riabinin was able to boil it to the required thickness without it undergoing unwanted fermentation, but only when he was personally present. In addition, the workers had a tendency to mix watery or fermented raw juice with good quality runs, jeopardizing the final product. ${ }^{86}$ But the problems with the winter did not stop there. On December 4, 1840, Riabinin wrote with bad news. The pond had frozen solid and all work had ceased. "The water is all gone and the machine stopped working on November 30th," he noted. ${ }^{87}$ In order to begin the first step of boiling the grated beets, water was necessary. Without it, the beets had backed up and 459 bushels' worth were waiting to be processed. ${ }^{88}$ Riabinin hoped they would not freeze, and stated somewhat 
plaintively that "the work had been going well from the cellar and the juice was very good, as were the sugar lumps." ${ }^{89}$

After the beets had been boiled, the resulting juice was purified by chemical means. The Bakhmetev factory used saltpeter, which is also used in gunpowder and for pickling meat. However, Riabinin stated that the juice was of poor quality and required a high percentage of saltpeter, and "I am afraid that after refining the saltpeter might remain in the granules. ${ }^{90}$ In addition, when the quality of the beets and juice was bad, more saltpeter was needed, which drove up production costs.

The use of complex machinery did not solve all problems. Riabinin complained several times of the lack of cleanliness at the factory, and particularly of the lax overseers who did not ensure that the machines were frequently cleaned. This was a problem, given the sticky nature of sugar making. Sometimes the machinery would break down or the resulting product would suddenly begin to vary, as in one case where a batch ended as "crystallized caramel" rather than as lump sugar. ${ }^{91}$ Even with the new machines, Riabinin noted the need for more forms for crystallizing the sugar, which would have required an extra expense for Bakhmetev; another time, Riabinin asked for more paper. ${ }^{92}$ Thus, although sugar refining was profitable, it was not easy for poorer nobles to take part. Any advanced equipment required access to capital, which was difficult for the reasons Baron Kots laid out. Here, the willingness of the MAS to spread what technical information they could was very important in decreasing the costs of entry, but over time even the Society could not help the smaller factory owners with all their needs.

The Moscow Agricultural Society played a key role in the early spread of beet sugar technology through its publications, which opened up networks of assistance to noblemen who owned few serfs, as well as wealthy ones. Malt'sov was the most important individual to encourage the spread of this branch of industry, both through his articles, which gave detailed plans of technology and budgets, and through his willingness to take on apprentices so that other landlords could train their own serfs to be directors of their beet sugar mills. In the 1830s and 1840s, the Moscow Society moved beyond this individualized promotion to a more coordinated approach, as the next section will show.

\section{The Committee of Sugar Beet Manufacturers nurses an infant industry}

38 From 1834, when members of the Moscow Agricultural Society established the Committee of Sugar Beet Manufacturers to 1848, when an excise on beet sugar solidified the transition to large sugar mills, the Committee provided interested nobles with technological assistance, commissioners to buy sugar, and access to an extensive network of enterprising landlords. After 1848, the industry had reached maturity and the Committee lost its importance, but only after having served the function of nurturing the infant industry into adulthood. In 1834, two years after a high tariff on cane sugar increased the price of that commodity and turned enterprising landlords' attention to producing beet sugar, the Moscow Agricultural Society established the Committee. ${ }^{93}$ They modeled it upon the Leipzig convocations of sheep breeders, which encouraged the exchange of advice and practical experience. ${ }^{94}$ 'sov, Bakhmetev, and others. Although the government did not provide the Committee 
with the 10,000 rubles a year subsidy they gave to the Moscow Society's equivalent committee on sheep raising, they did not attempt to hinder the society, either. Instead of a government subsidy, the members funded it, with most giving 50 rubles a year, which was a substantial sum. At one meeting in 1836, members donated 875 rubles; that year the Committee raised 1278 rubles, the majority of which they spent on their journal, with smaller amounts going to clerical help, the dissemination of improved seeds, and lighting the hall in which they met. ${ }^{95}$ This program of enlightenment reflects their priorities, the first of which was their journal, which they modeled on that of the beet sugar manufacturers of Paris. ${ }^{96}$ The example of Baron Kots showed the importance of the written word as a means to reach poorer nobles, who were not part of the more elevated social world of most of the Committee's members, who met in Moscow during the winter social season. The journal of the Committee of Sugar Beet Manufacturers sought to spread the technical and scientific practices of large growers to smaller producers as well so as to ensure a steady supply of raw material and encourage the more frequent use of sugar among as wide a population as possible. ${ }^{97}$

In addition to spreading practical knowledge, the Committee sought to establish the industry on a scientific basis by studying the best soil and the best strains of sugar beets. In addition, one of the reasons for the founding of the Committee was that some producers were receiving patents for inventions that had actually been known for some time, usually French in origin. ${ }^{98}$ The Committee sought to ensure that the best technology would not become proprietary knowledge, which would have slowed down the growth of the industry by raising barriers to entrance by smaller producers.

41 The cultural status of sugar beet refining was high, partly due to the work of the MAS, who encouraged nobles to produce beet sugar, arguing it was a form of business especially suitable for nobles. Here, the MAS benefited from the novelty of the sugar beet; already by the late 1820s, it had become fashionable for sugar beet factories to be established on wealthy estates. ${ }^{99}$ Although most such factories were rather primitive and had low productivity, they suggest that nobles had a motive to engage in sugar beet production, as it bolstered their consequence. In 1835, the MAS reported that sugar beet was an "industry very closely tied with agriculture, which is very proper for landlords who do not wish to go into trade." ${ }^{100}$ In addition, the MAS argued that the sugar beet industry "should predominantly belong to the noble class, as they have the land and labor to produce the raw material." 101

The stated focus of the Committee was practical: to avoid mistakes and to share advice. ${ }^{102}$ They helped beet sugar producers, especially smaller ones, by establishing several agents to sell seeds. Between 1831 and 1846, the Committee's agents sold 2,574,563 silver rubles' worth of sugar from the committee members. ${ }^{103}$ In addition, detailed plans and even models of the necessary equipment made establishing a sugar mill more possible for a larger number of landlords. ${ }^{104}$ The Committee even built a model sugar factory in Moscow, which soon had to close due to not being profitable. ${ }^{105}$ In 1839 , the Committee petitioned to open a refinery in Moscow so that the half-processed granules of nearby estates could be turned into the more refined and expensive white sugar. Tellingly, however, when a refinery was built, it was in Kiev in 1843, showing the shift from the Moscow to the Ukrainian provinces. ${ }^{106}$

43 The profitability of sugar beet and the difficulties of using serf labor in such advanced mechanized factories made many enterprising landlords aware of the limits of serfdom when combined with more advanced agriculture. This was also clear in the lack of 
qualified skilled personnel. When serfs were sent to become technicians and returned as basically the director of the factory, as had happened with Baron Kots' serf, it required literacy and an ability to command that sat uneasily with serfdom. In 1834, Aleksandr Dmitrievich Chertkov, who was a historian and archeologist whose library dealing with Russian history later served as one of the fundamental collections of the Historical Museum in Moscow, as well as a member of the Moscow Society and the Committee, opened a sugar mill in Voronezh. Chertkov believed that the production of sugar beet had a positive effect on the intellectual development of serfs and established a school for them. One of his serfs, Egor Mikhailovich Chekhov, worked as a clerk in the mill and was given its byproducts, which he used to feed his livestock. He began to trade in livestock for himself and for his master and in 1841 he bought out himself and his family. ${ }^{107}$ His grandson, the writer Anton Pavlovich Chekhov, was born into freedom in 1860.

In 1848 , the new excise on beet sugar was a turning point in the industry, confirming that the center of production had shifted to the Ukrainian provinces and that free labor was dominant there. Right-bank Ukraine, and particularly the area around Kiev, was an emerging center of beet sugar production, with large, technologically advanced factories that could be much more efficient in the amount of sugar produced from each beet. The smaller, less advanced factories that the MAS had done so much to encourage found it difficult to absorb the cost of the excise, and many went out of business. These sugar factories in Ukraine also underwent a shift to the use of free labor during this time, as the excise coincided with the imposition of inventories in right-bank Ukraine in 1847-1848; these inventories specified in great detail what services serfs owed their masters. The government sought to punish the landlords in the area, many of whom were Polish, through these inventories. ${ }^{108}$ As a result of the inventories and the excise, the large sugar factories in the region used free labor almost exclusively by the end of the 1840s. ${ }^{109}$

Some of the largest and most advanced sugar beet factories belonged to Count Aleksei Alekseevich Bobrinskii. By 1860-1861, his factories in Tula and Kiev provinces alone produced more than 9,027,500 pounds (4 514 tons) of sugar as well as having an associated coal mine to provide fuel for the machines. ${ }^{110}$ In his Studies on the Interior of Russia, based on an 1843 trip to Russia, August von Haxthausen described Bobrinskii's factory in Tula. Haxthausen was shown the factory by its manager, a German school friend of his, and he described it as a plant filled with modern inventions and producing sugar that he found to be just as good as that made from cane. ${ }^{111}$ The plant used hired labor and paid peasant women for beets. At the 1846 meeting of the Committee, MAS Secretary Maslov gave the first description of Bobrinskii's massive factory in Kiev, which had a sugar beet farm fifteen times the size of the largest amount of land devoted to growing them elsewhere. The land had 3500 serfs working on it, and the factory included the use of free labor, with a payroll of 60,000 paper rubles. ${ }^{12}$ The use of free labor in the Ukrainian provinces would only accelerate with the introduction of the inventories and the excise.

Sugar beet grows best in soils that have a mixture of sand and clay, and the areas in Ukraine that became centers of its production there are rich in such soils. There is a smaller area of suitable soil surrounding Kiev, but the largest area of this soil is found near Kherson, which produced the second largest crop in the region by 1901, after Baku. ${ }^{113}$ There were smaller areas of such soil in European Russia, but nowhere was there such a wide expanse as in southern Ukraine. ${ }^{114}$

In addition to a higher use of free labor, the factories in central and southern Ukraine were more technologically advanced compared to those in central Russia. This can be 
seen in the more widespread use of steam-driven technology in the sugar mills in Ukraine. Wood-fired beet sugar mills tended to be smaller, estate-based factories like those encouraged by the MAS. In contrast, in Ukraine, in 1848, 36 of 184 factories, or 20 percent, used steam. In central Russia, only 40 of 297 mills, or 13 percent, used steam. ${ }^{115}$ This difference, although not huge numerically, was very important at the moment when the excise was introduced, which rewarded more technologically advanced factories. The percentage of wood-burning factories in Ukraine fell from 80 to just 60 percent of the total from 1848 to $1857-58$, while in central Russia it only fell from 87 to 70 percent over the same period. ${ }^{116}$ Steam-powered factories were making greater inroads into Ukrainian factories than into ones in Central Russia.

This shift from central Russia to Ukraine and from smaller factories to large ones meant that the Committee lost its importance. The creation of a beet sugar refinery in Kiev in 1843, rather than in Moscow as the Committee had hoped, accelerated the shift to the Ukrainian provinces, as it was much easier to sell refined beet sugar than granules, which were a middle-stage product. ${ }^{117}$ The Committee began to die out in the second half of the 1840s. ${ }^{118}$ Although the Committee continued to meet and there was a special discussion about the excise in 1848 , such meetings became increasingly sporadic. In 1854, the twentieth anniversary of the founding of the Committee was observed, but this did not lead to its revitalization. By 1860, no mention of the Committee was made in the publications of the Moscow Society. ${ }^{119}$ Large factories no longer needed the tutelage of the Committee, and smaller factories often had had to close. ${ }^{120}$

The Southern Russian Agricultural Society, founded in Odessa in 1828 and the only agricultural society in the pre-reform Ukrainian provinces, did not take a leading role in encouraging the beet sugar industry. It published only two articles on beet sugar before $1861 .{ }^{121}$ A report covering their first 25 years of activity noted that sugar beet factories were spreading in Kiev and elsewhere and that some were connected to coal mines, which provided the fuel. The report congratulated the factory owners and stated that the Odessa society had been in contact with the Committee of the Moscow Society to distribute seeds and literature through the region, but did not note any independent action of the Odessa society. ${ }^{122}$ This lack of zeal can perhaps be explained by the rampant smuggling of refined sugar through Odessa. According to Russian laws, refined sugar could only be imported to Odessa as well as the Black Sea ports of the Caucasus. This measure was instituted in order to encourage the use of the ports, and it strictly forbade the distribution of sugar to the interior. However, the amount of refined sugar brought to Odessa increased fourfold between 1827 and 1846, and the amount was so large that it was impossible that it was all being consumed within that town. ${ }^{123}$ This may have made it difficult for all members of the Odessa society to agree that encouraging the production of beet sugar was worthwhile.

By the late nineteenth century, owners of large beet sugar mills were interested in voluntary associations to help them with their concerns, but those concerns had changed. Very large beet sugar mills produced mammoth amounts of sugar. The Mikhailov factory of Baron Tereshchenko in Chernigov province in Left-bank Ukraine alone produced an average of 75,837,790 pounds of beet sugar, equivalent to 37,918 tons, every year between 1907 and 1913, according to statistics kept by the Ministry of Transportation. ${ }^{124}$ Railroads enabled the transportation of such massive quantities throughout the empire. ${ }^{125}$ In 1897 , the All-Russian Society of Sugar Beet Producers was founded in Kiev. It was a specialized, scientific society that focused on studying the most productive strains of sugar beets, and 
they established experimental fields in private estates to do so in 1901, and a central experimental station in 1912. ${ }^{126}$ The broad-based propaganda of the Moscow Society no longer fit the more technical concerns of these sugar beet magnates. This also suggests the degree to which the sugar beet industry helped to stimulate science and industry in Ukraine. Bobrinskii's factory in Kiev helped to stimulate the development of a machine building industry in Ukraine, for example. ${ }^{127}$

\section{Conclusion}

The Moscow Agricultural Society played a crucial role in nurturing the infant industry of beet sugar production. It fed the infant industry by providing technical information on how to build factories and grow sugar beets, commissioners to sell the product, and access to a social network of many leading entrepreneurial landlords. This allowed a large number of nobles with smaller landholdings and fewer serfs to enter the market, which did indeed increase the base of raw materials and consumption of sugar, just as the MAS had hoped.

However, when the infant industry reached adulthood, the services of the Moscow Society were no longer needed. Large factory owners did not need assistance with seeds or sales, but were able to compete with cane sugar in the large domestic market, as well as in Asia. The Ukrainian beet sugar industry was particularly well positioned in the market, since it already had shifted to free labor before the end of serfdom and was using advanced equipment such as steam-driven machines. After 1861, sugar beet production exploded, from 70,414 tons in $1860-1861^{128}$ to 777,129 tons in 1897 , accounting for fifteen percent of the world's production of sugar beet. ${ }^{129}$ An average of 645,300 acres were sown in sugar beets over 1886 to 1895 and 1,425,805 acres (2227.8 square miles) were sown in $1901 . .^{130}$ In 1917, Russia produced 1,120,878 tons of sugar, more than any other country, aside from Germany. ${ }^{131}$ Most of the sugar was consumed at home, although some was exported to Asia. This was despite a precipitous drop in world sugar prices over the second half of the nineteenth century. Thus, Russian sugar production was a success because they were able to provide a product of a relatively consistent quality at a competitive price.

This article has shown that the Moscow Agricultural Society played an important, although transitory, role in the introduction of an industry into the Russian Empire that would prove to be an enduring success in the market. The sugar beet industry also was connected to the growth of free labor and industrialization in Ukraine, even before the abolition of serfdom, which helps to explain the divergent paths of Russia and Ukraine. Over the course of the nineteenth century, beet sugar moved from being a curiosity to becoming a force for change. 


\section{NOTES}

1. I.S. Koropeckyj, ed., Ukrainian Economic History : Interpretive Essays (Cambridge : Harvard Ukrainian Research Institute, 1991) ; Oleksander Ohloblyn, A History of Ukrainian Industry (Munich: Wilhelm Fink, 1971); Serhy Yekelchyk, Ukraine : Birth of a Nation (Oxford: Oxford University Press, 2007), 54-57.

2. For an excellent overview of the development of Ukrainian historical narrative, see Serhii Plokhy, Unmaking Imperial Russia : Mykhailo Hrushevsky and the Writing of Ukrainian History (Toronto : University of Toronto, 2005).

3. Andreas Kappeler, "From an Ethnonational to a Multiethnic to a Transnational Ukrainian History," in Georgiy Kasianov and Philipp Ther, eds., A Laboratory of Transnational History: Ukraine and Recent Ukrainian Historiography (Budapest : Central European University Press, 2009), 51-80. For an economic take on the multiethnic narrative, see Theodore H. Friedgut, Iuzovka and Revolution, vol. 1 and 2 (Princeton : Princeton University Press, 1989-1994). See also the articles on the present Ukrainian crisis in historical perspective in Kritika : Explorations in Russian and Eurasian History, 16, 1 (Winter 2015).

4. Bernd Bonwetsch, Die russische Revolution 1917: Eine Sozialgeschichte von der Bauernbefreiung 1861 bis zum Oktoberumsturz (Darmstadt : Wissenschaftliche Buchgesellschaft, 1991) ; Peter Gatrell, The Tsarist Economy 1850-1917 (London: B.T. Batsford, 1986) ; Andrzej Walicki, The Controversy over Capitalism: Studies in the Social Philosophy of the Russian Populists (New York: Oxford University Press, 1969). See also V.I. Lenin, The Development of Capitalism in Russia (M. : Progress Publishers, 1977).

5. Alexander Gerschenkron, Continuity in History and other Essays (Cambridge: Harvard University Press, 1968). Other classic state-centered narratives include: Theodore von Laue, Sergei Witte and the Industrialization of Russia (New York: Columbia University Press, 1963); Alexander Gerschenkron, "Problems and Patterns of Russian Economic Development," in Cyril E. Black, ed., The Transformation of Russian Society (Cambridge: Harvard University Press, 1960) : 42-72.

6. Carol S. Leonard, Agrarian Reform in Russia : The Road from Serfdom (Cambridge : Cambridge University Press, 2011).

7. Olga Crisp, Studies in the Russian Economy before 1914 (New York : Barnes and Noble, 1976); Paul Gregory, Russian National Income, 1885-1913 (Cambridge: Cambridge University Press, 1982) ; Arcadius Kahan, Russian Economic History : The Nineteenth Century (Chicago : University of Chicago Press, 1989) ; Richard L. Rudolph, "Agricultural Structure and Proto-Industrialization in Russia : Economic Development with Unfree Labor," Journal of Economic History, 45, 1 (March 1985) : 47-69.

8. An excellent example both of the critique and the intellectual turn is Frank Wcislo, "Rereading Old Texts : Sergei Witte and the Industrialization of Russia," in Susan P. McCaffray and Michael Melancon, eds., Russia in the European Context, 1789-1914 : A Member of the Family (New York : Palgrave Macmillan, 2005), 70-83. See also Vincent Barnett and Joachim Zweynert, eds., Economics in Russia: Studies in Intellectual History (Burlington, VT : Ashgate, 2008); Esther Kingston-Mann, In Search of the True West: Culture, Economics, and Problems of Russian Development (Princeton : Princeton University Press, 1999) ; Yanni Kotsonis, Making Peasants Backward : Agricultural Cooperatives and the Agrarian Question in Russia, 1861-1914 (New York : St. Martin's Press, 1999) ; Thomas C. Owen, Dilemmas of Russian Capitalism : Fedor Chizhov and Corporate Enterprise in the Railroad Age (Cambridge: Harvard University Press, 2005); 
Alessandro Stanziani, "Free Labor - Forced Labor : An Uncertain Boundary? The Circulation of Economic Ideas between Russia and Europe from the 18th to the Mid-19th Century," Kritika : Explorations in Russian and Eurasian History 9, 1 (Winter 2008) : 27-52 ; Joachim Zweynert, Eine Geschichte des ökonomischen Denkens in Russland, 1805-1905 (Marburg: Metropolis Verlag, 2002).

9. Stepan Maslov, Istoricheskoe obozrenie deistvii i trudov imperatorskogo Moskovskogo obshchestva sel'skogo khoziaistva so vremeni ego osnovanii do 1846 goda [Historical overview of the actions and works of the imperial Moscow Agricultural Society from the time of its founding until 1846] (M. : V universitetskoi tipografii, 1850) ; A.P. Perepelkin, Istoricheskaia zapiska o 30-ti letnei deiatel'nosti Moskovskogo obshchestva sel'skogo khoziaistva i ego prezidenta I.N. Shatilova [Historical survey of the 30 years of activity of the Moscow Agricultural Society and its president I.N. Shatilov] (M. : A.A. Levenson, 1890). See also : B.V. Tikhonov, 'Obzor 'zapisok' mestnykh sel'skokhoziaistvennykh obshchestv 30-50-kh godov XIX v. [An overview of the 'Notes' of local agricultural societies of the 1830s-1850s]," in A.N. Nasonov and A.A. Novosel'skii, eds., Problemy istochnikovedeniia [Problems of Source Studies], vyp. 9 (M. : Nauka, 1961).

10. Michael Confino, Domaines et seigneurs en Russie vers la fin du XVIII ${ }^{\mathrm{e}}$ siècle; étude de structures agraires et de mentalités économiques (P.: Institut d'études slaves, 1963); Idem, Systèmes agraires et progrès agricole : l'assolement triennal en Russie aux XVIII ${ }^{\mathrm{e}}-\mathrm{XIX}^{\mathrm{e}}$ siècles (P. : Mouton, 1969) ; N.S. Trusova and O.A. Bliumfel'd, "Iz istorii vozniknoveniia i nachal'noi deiatel 'nosti Moskovskogo obshchestva sel'skogo khoziaistva (1820-1830 gg.) [From the history of the origin and early activity of the Moscow Agricultural Society (1820-1830)]," Materialy po istorii sel 'skogo khoziaistva i krest'ianstva SSSR, 3 (1959) : 280-324.

11. David Moon, The Russian Peasantry, 1600-1930: The World the Peasants Made (London: Longman, 1999), 131.

12. Tracy Dennison, The Institutional Framework of Russian Serfdom (Cambridge: Cambridge University Press, 2011). Works on regional economic development include : Heinz-Dietrich Löwe, Die Lage der Bauern in Russland 1880-1905. Wirtschaftliche und soziale Veränderungen in der Gesellschaft des Zarenreiches (St. Katharinen : Scripta Mercaturae Verlag, 1987) ; Edgar Melton, "Proto-Industrialization, Serf Agriculture and Agrarian Social Structure: Two Estates in Nineteenth-Century Russia," Past and Present, 115, 1 (May 1987) : 69-106.

13. Joseph Bradley, Voluntary Associations in Tsarist Russia: Science, Patriotism and Civil Society (Cambridge : Harvard University Press, 2009), 38-85 ; O.Iu. Elina, “Sel'skokhoziaistvennye obshchestva Rossii, 1765-1920-e gody: vklad v razvitie agronomii [Agricultural societies in Russia, 1765-1920s : Contributions to the development of agronomy]," Rossiiskaia istoriia, no. 2 (2011) : 27-45 ; M.M. Frolova, "Moskovskoe obshchestvo sel'skogo khoziaistva i sveklosakharnye zavody A.D. Chertkova [The Moscow Agricultural Society and the sugar beet factory of A.D. Chertkhov]," Voprosy istorii, no. 11 (2011): 94-109; A.A. Kurenyshev, Sel 'skokhoziaistvennaia stolitsa Rossii: Ocherki istorii Moskovskogo obshchestva sel'skogo khoziaistva (1818-1929 gg.) [The agricultural capital of Russia: Essays in the history of the Moscow Agricultural Society (1818-1929)] (M.: AIRO-XXI, 2012); Colum Leckey, Patrons of Enlightenment: The Free Economic Society in Eighteenth-Century Russia (Newark, DE: University of Delaware Press, 2011); David Moon, The Plough that Broke the Steppes: Agriculture and Environment on Russia's Grasslands, 1700-1914 (Oxford: Oxford University Press, 2013).

14. Ilya Gerasimov, Modernism and Public Reform in Imperial Russia : Rural Professionals and Self-organization, 1905-1930 (New York: Palgrave Macmillan, 2009) ; S.A. Kozlov, Agrarnye traditsii i novatsii $\mathrm{v}$ doreformennoi Rossii (tsentral'no-nechernozemnye gubernii) [Agrarian traditions and innovations in pre-reform Russia (the central non-black earth region)] (M.: ROSSPEN, 2002). 
15. K.G. Voblyi, Opyt istorii sveklo-sakharnoi promyshlennosti SSSR [An essay on the history of the beet sugar industry of the USSR] (M. : Pravleniia sakharotresta, 1928), $1: 114$.

16. Sidney Mintz, Sweetness and Power: The Place of Sugar in Modern History (New York: Viking, 1985).

17. V.T. Krasochkin, "Iz istorii vozdelyvaniia svekly [From the history of the cultivation of the sugar beet]," Materialy po istorii sel'skogo khoziaistva i krest'ianstva SSSR (1960), 4: 479; Elizabeth Abbott, Sugar : A Bittersweet History (New York : Duckworth Overlook, 2008), 182.

18. Abbott, Sugar: A Bittersweet History; Ph.G.Chalmin, "The Important Trends in Sugar Diplomacy before 1914," in Bill Albert and Adrian Graves, eds., Crisis and Change in the International Sugar Economy, 1860-1914 (Edinburgh : ISC Press, 1984), 9.

19. Krasochkin, "Iz istorii vozdelyvaniia svekly," 483.

20. Krasochkin, "Iz istorii vozdelyvaniia svekly," 483 ; Roger Munting, "The State and the Beet Sugar Industry in Russia before 1914," in Albert and Graves, eds., Crisis and Change, 22.

21. Munting, "The State and the Beet Sugar Industry," 24 ; Frolova, "Moskovskoe obshchestvo," 94.

22. "Noveishie otkrytiia i zamechaniia [The newest discoveries and notes]," Kazanskie izvestiia, no. 18 (May 4, 1812) : 1-2.

23. Harold McGee, On Food and Cooking : The Science and Lore of the Kitchen (New York : Collier Books, 1984), 389.

24. Voblyi, Opyt istorii, 389.

25. K. Lodyzhenskii, Istoriia Russkogo tamozhennogo tarifa [History of the Russian tariff] ( $\mathrm{SPb}$. : Tip. V.S. Balasheva, 1886), 279.

26. Frolova, "Moskovskoe obshchestvo," 94.

27. Voblyi, Opyt istorii, 90.

28. Moon, The Russian Peasantry, 136.

29. Lodyzhenskii, Istoriia Russkogo tamozhennogo tarifa, 279.

30. Munting, "The State and the Beet Sugar Industry," 24.

31. Frolova, "Moskovskoe obshchestvo," 103 ; Lodyzhenskii, Istoriia Russkogo tamozhennogo tarifa, 279.

32. Frolova, "Moskovskoe obshchestvo," 94.

33. Voblyi, Opyt istorii, 128.

34. Munting, "The State and the Beet Sugar Industry," 24.

35. Alison Smith, Recipes for Russia : Food and Nationhood under the Tsars (DeKalb, IL : Northern Illinois University Press, 2008).

36. Walter Pintner, Russian Economic Policy under Nicholas I (Ithaca : Cornell University Press, 1967), 223-224.

37. Pintner, Russian Economic Policy under Nicholas I, 223-224.

38. Munting, "The State and the Beet Sugar Industry," 22.

39. Frolova, "Moskovskoe obshchestvo," 103.

40. Frolova, "Moskovskoe obshchestvo," 103 ; Lodyzhenskii, Istoriia Russkogo tamozhennogo tarifa, 279.

41. Munting, "The State and the Beet Sugar Industry," 23.

42. Voblyi, Opyt istorii, 393.

43. Voblyi, Opyt istorii, 393.

44. Munting, "The State and the Beet Sugar Industry," 24.

45. Frolova, "Moskovskoe obshchestvo," 103.

46. "Keppen, Petr Ivanovich," Ėntsiklopedicheskii slovar F.A. Brokgauza i I.A. Efrona (http:// www.vehi.net/brokgauz/index.html). Accessed August 2, 2012.

47. SPF RAN (Sankt-Petersburgskii filial Arkhiva Rossiiskoi Akademii nauk - St. Petersburg Branch of the Archive of the Russian Academy of Sciences), f. 30, lichnyi fond P.I. Keppena 
[Personal file of P.I.Keppen], op.3, d.165, Pis'ma S.A. Maslova k P.I. Keppenu [Letters of S.A. Maslov to P.I. Keppen], 1. 11-11ob.

48. Frolova, "Moskovskoe obshchestvo," 101, 103 ; Voblyi, Opyt istorii, 390.

49. Voblyi, Opyt istorii, 391-392.

50. Polnoe sobranie zakonov Rossiiskoi imperii [The complete collection of laws of the Russian Empire] (SPb. : Tip. II-go Otdeleniia Sobstvennoi E.I.V. Kantseliarii, 1849), 23 : No. 22024.

51. Frolova, "Moskovskoe obshchestvo," 105.

52. Bill Albert and Adrian Graves, "Introduction," in Albert and Graves, eds., Crisis and Change, 3.

53. Chalmin, "The Important Trends in Sugar Diplomacy," 10 ; Noel Deerr, The History of Sugar (London : Chapman and Hall, 1950), 2 : 492-498.

54. James R. Lehning, "Agriculture," in Peter N. Stearns, ed., Encyclopedia of European Social History from 1350 to 2000 (New York : Scribner's, 2001), 2 : 348.

55. Folke Dovring, "The Transformation of European Agriculture," in H.J. Habakkuk and M. Postan, eds., The Cambridge Economic History of Europe (Cambridge : Cambridge University Press, 1965), $6: 636$.

56. Giovanni Federico, Feeding the World: An Economic History of Agriculture, 1800-2000 (Princeton, 2005), 108-109 ; On the Free Economic Society, see Leckey, Patrons of Enlightenment.

57. Federico, Feeding the World, 108-109; Philip J. Pauly, Fruits and Plains : The Horticultural Transformation of America (Cambridge, MA, 2007), 53.

58. Federico, Feeding the World, 108-109.

59. Kotsonis, Making Peasants Backward.

60. Kozlov, Agrarnye traditsii i novatsii, 403.

61. Kozlov, Agrarnye traditsii i novatsii, passim.

62. I.N. Konovalov, Sel'skokhoziaistvennaia kooperatsiia povolzh'ia $v$ istorii i kul'ture Rossii [Agricultural cooperation in the Volga region in the history and culture of Russia] (Saratov: Saratovskii universitet, 2003), 23-24 ; S.A. Kozlov, "175 let Moskovskomu obshchestvu sel'skogo khoziaistva : traditsii i novatsii [175 years of the Moscow Agricultural Society: Traditions and innovations]," Nauchnye trudy mezhdunarodnogo soiuza èkonomistov i Vol'nogo èknomicheskogo obshchestva Rossii, no.3 (1996): 236. For a negative evaluation of the cooperative movement that emphasizes the shared interests and actions of the agricultural societies and the state, see Kotsonis, Making Peasants Backward. Focusing on parallel structures of thought between cooperative activists and colonizers, Kotsonis' work is an important early work in the intellectual turn in Russian economic history. For a more positive evaluation of cooperatives, see Gerasimov, Modernism and Public Reform.

63. A.V. Chaianov, "Osnovnye linii razvitiia russkoi sel'sko-khoziaistvennoi mysli za dva veka [The foundational lines of development of Russian agricultural thought for two centuries]," in Rikhard Krtsimovskii, ed., Razvitie osnovnykh printsipov nauki o sel'skom khoziaistve v zapadnoi Evrope [The development of foundational principles of agricultural science in Western Europe] (M. : Novyi agronom, 1927), 27-41.

64. Maslov, Istoricheskoe obozrenie, 73-75.

65. See Minister of Finances Kankrin's letter to Gagarin, dated June 30, 1836, printed in Maslov, Istoricheskoe obozrenie.

66. State peasants were owned by the state rather than by nobles. See W. Bruce Lincoln, In the Vanguard of Reform : Russia's Enlightened Bureaucrats, 1825-1861 (DeKalb, IL : Northern Illinois University Press, 1982), 30-36 and passim.

67. Maslov, Istoricheskoe obozrenie, 129.

68. Maslov, Istoricheskoe obozrenie, $2^{\text {nd }}$ collation, 77.

69. Maslov, Istoricheskoe obozrenie, $2^{\text {nd }}$ collation, 78.

70. RGIA (Rossiiskii gosudarstvennyi istoricheskii arkhiv - Russian State Historical Archive), f. 940, Lichnyi fond A.P. Zablotskogo-Desiatovskogo [Personal file of A.P. Zablotskii-Desiatovskii], 
op. 1, d. 225, Pis'ma S.A. Maslova k A.P.Zablotskomu-Desiatovskomu [Letters of S.A. Maslov to A.P. Zablotskii-Desiatovskii], 1. 4. I would like to thank Olga Bol'shakova for bringing this source to my attention.

71. Voblyi, Opyt istorii, 91.

72. Voblyi, Opyt istorii, 92.

73. Voblyi, Opyt istorii, 91.

74. Voblyi, Opyt istorii, 118.

75. Voblyi, Opyt istorii, 110, 381.

76. Frolova, "Moskovskoe obshchestvo," 97.

77. "Bakhmetevy," Russkii biograficheskii slovar' (http://rulex.ru/01021058.htm) (Accessed July 20, 2015)

78. In 1820, an agricultural school was established in Penza. Kozlov, Agrarnye traditsii i novatsii, 149.

79. TsIAM (Tsentral'nyi istoricheskii arkhiv Moskvy - Central Historical Archive in Moscow), f. 1845 (semeinyi fond Bakhmetevykh-Tolstykh), op. 3, d. 82 (Reports of steward of beet sugar factory Porfirii Riabinin to A.N. Bakhmetev on economic questions). The village was also known as Nikol'skoe and Pestrovka.

80. Maslov, Istoricheskoe obozrenie, 258.

81. Frolova, "Moskovskoe obshchestvo," 98.

82. Voblyi, Opyt istorii, 108.

83. Tikhonov, "Razvitie," 131. The other was owned by Fedor Vasil'evich Samarin, the father of the Slavophile Iurii Samarin. Slavophiles were involved in sugar beet production, with Aleksei Stepanovich Khomiakov having a successful beet sugar mill, among others. E.A. Dudzinskaia, Slavianofily v obshchestvennoi bor'by [Slavophiles in the social conflict] (M. : Mysl', 1983), 65. In this, the sugar beet industry helped them to achieve their goal of being independent gentlemen. Michael Hughes, “'Independent Gentlemen' : The Social Position of the Moscow Slavophiles and its Impact on their Social Thought," Slavonic and East European Review 71, 1 (January 1993) : 66-88.

84. TsIAM, f. 1845 , op. 3 , d. $82,1.3$.

85. TsIAM, f. 1845 , op. 3 , d. 82, 1. 7.

86. TsIAM, f. 1845 , op. 3 , d. $82,1.60 b$

87. TsIAM, f. 1845 , op. 3 , d. $82,1.10$

88. Or 5259 chetvert. One chetvert equals .0872611 bushels.

89. TsIAM, f. 1845, op. 3, d. 82, 1. 10 ob.

90. TsIAM, f. 1845, op. 3, d. 82, 1.10ob. Later, Riabinin noted that the finished product did not have saltpeter in it, although the granules, a middle stage product, did. Ibid, l. 13.

91. TsIAM, f. 1845, op. 3, d. 82, 1. 3.

92. TsIAM, f. 1845, op. 3, d. 82, 1. 11ob.

93. Frolova, "Moskovskoe obshchestvo," 98.

94. Frolova, "Moskovskoe obshchestvo," 97.

95. Frolova, "Moskovskoe obshchestvo," 98.

96. Voblyi, Opyt istorii, 113.

97. Voblyi, Opyt istorii, 111-120.

98. Voblyi, Opyt istorii, 109.

99. Voblyi, Opyt istorii, 96.

100. Voblyi, Opyt istorii, 114.

101. Voblyi, Opyt istorii, 114.

102. Frolova, "Moskovskoe obshchestvo," 97. 
103. Maslov, Istoricheskoe obozrenie, 122. In the nineteenth century, Russia had two currencies, namely, silver rubles and rubles assignat (paper), which had a varying exchange rate. Silver rubles were more valuable than paper ones.

104. Voblyi, Opyt istorii, 121.

105. Voblyi, Opyt istorii, 122.

106. Voblyi, Opyt istorii, 129, 138.

107. Frolova, "Moskovskoe obshchestvo," 101-102.

108. David Moon, "The Inventory Reform and Peasant Unrest in Right-Bank Ukraine in 1847-48," Slavonic and East European Review, 79, 4 (October 2001) : 653-697.

109. Takesi Matsumura, "Transformatsiia derevni na Pravoberezhnoi Ukraine nakaune osvobozhdeniia krest'ian i rol' inventarnykh pravil [The transformation of villages in Right-Bank Ukraine on the eve of the emancipation of the peasants and the role of inventories]," in Kimitaka Matsuzato, ed., Sotsial'naia transformatsiia i mezhetnicheskie otnosheniia na Pravoberezhnoi Ukraine : 19 - nachalo 20 vv. : Sbornik stat'ei [Social transformations and multiethnic relations in Right-Bank Ukraine] (Sapporo, Japan : Slavic Research Center, 2005), 61-88.

110. B.V. Tikhonov, "Razvitie sveklosakharnoi promyshlennosti vo vtoroi polovine $40-\mathrm{kh}$ i v 50-kh godakh XIX veka ( $\mathrm{k}$ istorii nachala promyshlennogo perevorota) [The development of beet sugar industry in the late 1840s and 1850s (towards the history of the origins of the Industrial Revolution)]," Istoricheskie zapiski 62 (1958) : 145, 150. Maslov noted that by 1845, Bobrinskoi's sugar was newly for sale in Romny (Poltava Province), Kharkov and Orel. SPF RAN, f. 30, op. 3, d. $165,1.11$.

111. August von Haxthausen, Studies on the Interior of Russia, ed. S. Frederick Starr and trans. Eleanore Schmidt (Chicago : University of Chicago Press, 1972), 221.

112. Voblyi, Opyt istorii, 134.

113. A.V. Voronina, Pochvennaia karta Ukrainskoi SSR [Soil map of the Ukrainian SSR] (M., 1977) ; "Summarnoe otpravlenie rafinada so stantsii Iugo-zapadnogo kraia v 1901," unnumbered plate in M.A. Davydov, Vserossiiskii rynok v kontse XIX - nachale XX vv. i zheleznodorozhnaia statistika [The All-Russian market in the late nineteenth- early twentieth centuries and railroad statistics] (SPb. : Aletiia, 2010).

114. V.M. Fridland et al., eds., Pochvennaia karta RFSFR [Soil map of the RFSFR] (M., 1988).

115. T.I. Derev'iankin, ed., Istoriia narodnogo gospodarstva Ukrainsk'oi RSR [History of the economy of the Ukrainian SSR] (Kiev : Naukova Dumka, 1983), $1: 244$.

116. Derev'iankin, ed., Istoriia narodnogo gospodarstva Ukrainsk'oi RSR.

117. Voblyi, Opyt istorii, 138.

118. Voblyi, Opyt istorii, 138.

119. Voblyi, Opyt istorii, 139-141.

120. Frolova, "Moskovskoe obshchestvo," passim.

121. A.S. Borinevich, Sistematicheskii ukazatel' statei, zametok, protokolov, otchetov i proch., pomeshchennykh v 'Listakh' i 'Zapiskakh' Imperatorskogo Obshchestva Sel'skogo Khoziaistva Iuzhnoi Rossii s 1830 po 1894 g. [Systematic index of articles, notes, minutes, reports, etc., listed in the 'Pages' and 'Notes' of the imperial Southern Russian Agricultural Society] (Odessa, 1895), 31.

122. Otchet o deistviiakh imperatorskogo obshchestva sel'skogo khoziaistva Iuzhnoi Rossii [Report on the activity of the imperial Southern Russian Agricultural Society] (Odessa, 1855), 120-122.

123. G.P. Nebolsin, Statisticheskoe obozrenie vneshnei torgovli Rossii (SPb., 1850), 330-331.

124. Davydov, Vserossiiskii rynok, 436.

125. Davydov, Vserossiiskii rynok, 436 ; Gatrell, Tsarist Economy.

126. Elina, "Sel'skokhoziaistvennye obshchestva," 36.

127. Voblyi, Opyt istorii, 395. 
128. V.K. Iatsunskii, "Krupnaia promyshlennost' Rossii v 1790-1860 gg. [Heavy industry in Russia from 1790-1860]," in M.K. Rozhkova, ed., Ocherki ékonomicheskoi istorii Rossii pervoi poloviny XIX veka [Essays in the economic history of Russia in the early $19^{\text {th }}$ century] (M. : Izd. Sotsial 'no-ekon. literatury, 1959), 196. These are short tons, converted from the pood.

129. Deerr, The History of Sugar, 491, 493. These figures are converted from metric tons to U.S. short tons $(2000 \mathrm{lb})$. One metric ton is equivalent to 2204.6 American pounds.

130. Lenin, The Development of Capitalism in Russia, 296.

131. Deerr, The History of Sugar, 492-498. The First World War did not significantly change the trend ; already by 1913, Russia had overtaken France and Austria-Hungary, two countries that had previously produced more. Ibid., 492-494.

\section{ABSTRACTS}

This article explores how agricultural societies, which were voluntary associations dedicated to improving agriculture, worked with the state and agriculturalists to foster the growth of a new sugar beet industry during the nineteenth century. Using the Moscow Agricultural Society (est. 1818) as the focal point, it argues that although the Society was successful in changing agricultural practices and spreading the cultivation of sugar beets even before the end of serfdom in 1861, the end result was not what the Society had expected. While they had originally envisioned a European Russia dotted with small producers growing sugar beet processed by larger landowners, what resulted was the rise of massive vertically integrated beet sugar production in central and southern Ukraine, which had more suitable soil and wider use of free labor. It thus shows the power of experts to change the environment and the limits of that power

Cet article étudie comment, au XIX ${ }^{\mathrm{e}}$ siècle, des sociétés agricoles, qui étaient des associations bénévoles engagées dans l'amélioration de l'agriculture, travaillèrent avec l'État et les agriculteurs à favoriser l'expansion d'une nouvelle industrie de la betterave sucrière. Prenant la Société agricole de Moscou (fondée en 1818) comme point focal, il démontre que celle-ci, bien qu'elle eût réussi à changer les pratiques et à étendre la culture de la betterave sucrière avant même l'abolition du servage en 1861, n'avait pas obtenu le résultat escompté. Alors que la Société agricole de Moscou avait initialement imaginé une Russie européenne dotée de petits producteurs éparpillés cultivant de la betterave qui aurait été transformée par de grands propriétaires fonciers, elle constata l'augmentation d'une production de masse à intégration verticale en Ukraine centrale et méridionale, dont la qualité des terres était plus adaptée à cette culture et qui disposait plus largement d'une main d'œuvre gratuite. L'article démontre ainsi le pouvoir des experts, et ses limites, à changer l'environnement.

\section{AUTHOR}

\section{SUSAN SMITH-PETER}

College of Staten Island / CUNY Department of History, Susan.smithpeter@csi.cuny.edu 